\title{
Are Resource-Rich Countries More Attractive than Countries with Good Institutions to Foreign Direct Investors in Sub-Saharan Africa?
}

\author{
Muhammad Akhtaruzzaman ${ }^{1}$, Shaohua Yang ${ }^{2}$ \& Azizah Omar $^{3}$ \\ ${ }^{1}$ Business Lecturer, Faculty of Business, Management and Legal Studies, Toi Ohomai Institute of Technology, \\ Rotorua, New Zealand \\ ${ }^{2}$ Ph.D. Student, School of Management, Universiti Sains Malaysia, Penang, Malaysia \\ ${ }^{3}$ Associate Professor, School of Management, Universiti Sains Malaysia, Penang, Malaysia \\ Correspondence: Shaohua Yang, Ph.D. Student, School of Management, Universiti Sains Malaysia, Penang, \\ Malaysia. E-mail: samuelyang0713@hotmail.com
}

Received: March 15, 2018

Accepted: April 25, 2018

Online Published: April 30, 2018

doi:10.5539/ijef.v10n6p65

URL: https://doi.org/10.5539/ijef.v10n6p65

\begin{abstract}
Africa is no longer behind in the race of acquiring global share of foreign direct investment (FDI) compared to other developing regions. This study uses FDI dataset of 27 sub-Saharan African (SSA) countries and examines what drives the recent trend of higher FDI flows to Africa. A variety of empirical techniques (e.g. cross-section OLS, panel fixed effects and dynamic GMM) are employed for identifying main drivers of FDI in African countries. The finding of this research suggests that resource endowment is the main driver attracting FDI to SSA countries. More specifically, empirical estimates suggest that a one-standard deviation increase in resource endowment in the SSA countries is associated with an increase in FDI ranging from 34\% to 83\%. Empirical result also suggests that between institutions and resource endowment, resource endowment is the most robust determinant of FDI in SSA countries.
\end{abstract}

Keywords: foreign direct investment, resource endowment, institutional quality

\section{Introduction}

An observation in FDI (foreign direct investment) literature studied African countries is that Africa has largely failed to attract much FDI compared to other developing regions (e.g., Asiedu, 2002; Nunnenkamp \& Spatz, 2002; Ezeoha \& Cattaneo, 2012). Empirical models are employed to identify the factors responsible for low FDI inflows among African states. The story is no longer true as Africa is now an attractive destination for FDI. Table 1, the growth rates of FDI inflows to different developing regions from 1990-2014. Asia and Latin America and Caribbean had experienced much stronger growth in FDI inflows from 1990-2000. However, from 2001-2014, Africa was leading with Asia in attracting FDI and experienced $17.38 \%$ average annual growth in FDI. This changing pattern in FDI suggests that Africa is no longer lagging behind other developing regions and Africa becomes an attractive destination for FDI.

Table 1. Average annual growth of FDI inflows to different developing regions

\begin{tabular}{lcc}
\hline Region/Economy & $1990-2000$ & $2001-2014$ \\
\hline Developing Economies & $21.74 \%$ & $9.46 \%$ \\
Africa & $15.74 \%$ & $17.38 \%$ \\
Asia & $21.67 \%$ & $17.38 \%$ \\
Latin America and Caribbean & $28.83 \%$ & $8.91 \%$ \\
\hline
\end{tabular}

Source: UNCTAD, FDI/TNC, database, June 2015.

Since 1990s, sub-Saharan Africa and Latin America and Caribbean account for about half of global discoveries of metals (base metals: iron ore, copper, aluminium, and nickel). Literature argues that frontier markets (FM) in Africa outperforms other emerging markets in other regions and attracts higher amount of private capital flows as a result of improved institutional environment, natural resource richness, financial market development, growth prospects, and better macro-economic policies (Note 1). 
The world has evidenced a large and long upward swing in commodity prices dominated by metal prices since 2009 to till 2013 (IMF Primary Commodity Price System, 2016). A cursory look of Figure 1 suggests a coincidence of the timing of institutional development and an increase in the share of global discoveries in SSA and Latin America and Caribbean. It apparently suggests that increased growth of FDI in the SSA (as shown in Table 1) might have been driven by improvements in institutional environment.

Figure 2 presents rather a clearer picture on evaluations of institutional improvements and its relation to resource endowments and FDI inflows in the 26 SSA countries over the time periods (Note 2). Figure $2 \mathrm{~b}$ suggests that a significant improvement in institutional environment took place in the SSA countries from the early to mid-1990s, which seems to show a downward trend in the later years. On the other hand, Figure 2c suggests an upward trend in resource endowment since the early 2000s. FDI per capita in Figure 2a also shows an increasing trend in the SSA countries since the early 2000s. This research investigates whether resource endowment or institutional quality had driven the FDI in the SSA countries.

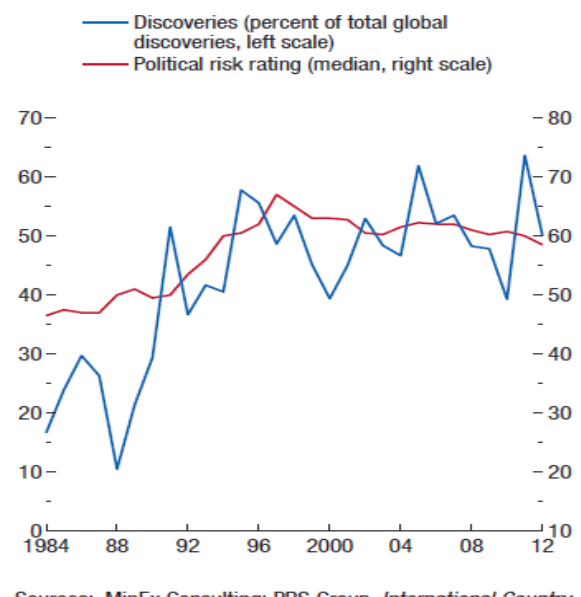

Sources: MinEx Consulting; PRS Group,
Risk Guide; and IMF staff calculations.

Figure 1. Correlation between institutional quality and global share of metal discoveries in Latin America and

Caribbean and sub-Saharan Africa

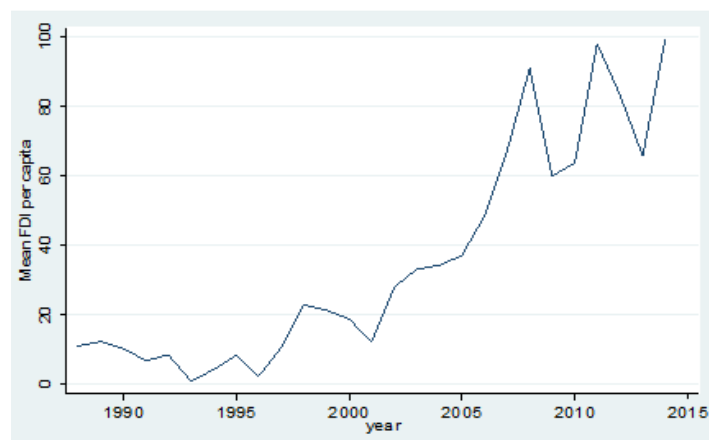

Figure 2a. Mean FDI per capita (1988-2014) of 26 SSA countries

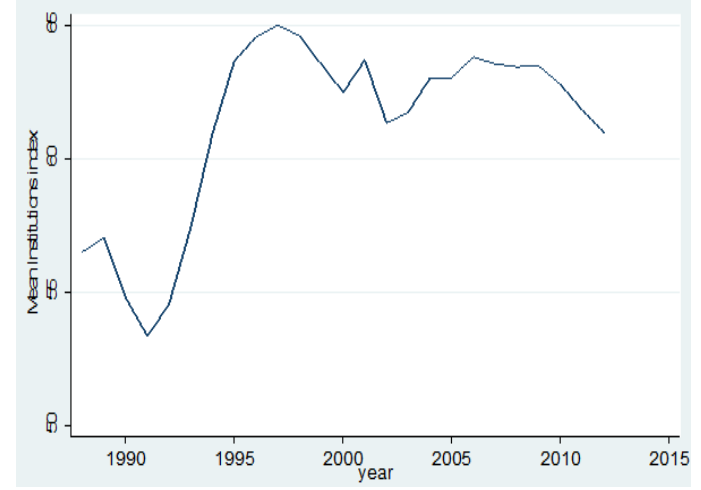

Figure 2b. Mean institutions index (1988-2014)

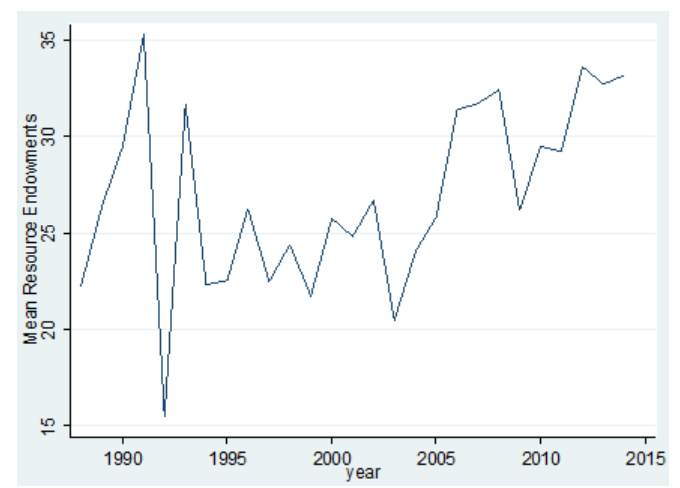

Figure 2c. Mean resource endowments (1988-2014) 
However, bivariate plot analysis does not provide sufficient information on the relationship of the variables resource endowment and institutional quality as potential determinants of FDI in the SSA countries. It is therefore tempting to investigate whether increasing trends in recent FDI data in these countries are driven by improvement in institutional development or by resource endowments. In relation to this research objective, this paper examines an established argument in existing literature that suggests improved institutional environment are required in the SSA countries to attract higher FDI inflows (e.g. Asiedu, 2006; Naude \& Kugell, 2007). However, contrasting trends between the development of institutional environment and resource endowment as shown in Figure 2 lead this project to empirically examine whether higher FDI flows to SSA countries are determined by improved institutional environment or by increased resource endowment. In particular, assuming all other characteristics are the same, a country in the SSA attracts a higher level of FDI for being a higher resourced-rich or for being better in institutional environment. It also examines, if institutional environment is too broad to capture the effect on FDI, improvement of which particular aspect of the institutional environment is relatively more effective in attracting FDI in the SSA countries. The remainder of the paper is organised as follows: Section 2 presents literature review, Section 3 presents empirical model and description of the data and explanatory variables, Section 4 presents empirical results and discussion of the results, Section 5 concludes.

\section{Survey of Literature}

The studies (e.g., Akhtaruzzaman, Berg, \& Hajzler, 2017) investigating the determinants of capital flows are vast and they examined different types of determinants (e.g., macroeconomic, institutional) for different types of capital flows (e.g., FDI, portfolios, debt) to developing countries. Alfaro et al. (2008), a highly cited study in this literature, examines the direction of capital flows and suggests that lack of institutional development is the main reason why capital doesn't flow from rich to poor countries (i.e., the Lucas Paaradox, 1990). The explanation of lack of institutional development as a main reason for lack of capital flows to developing countries is reviewed in several recent studies (e.g., Akhtaruzzman, Hajzler, \& Owen, 2017) however, the solution is not confirmed. Other studies (e.g. Akhtaruzzaman, Berg, \& Lien, 2017) examined determinants of bilateral FDI flows between China and African countries. Review of the existing literature on FDI to Africa suggests a large number of studies empirically investigated the macroeconomic determinants of FDI for African countries. This research focuses mainly on empirical studies that examined the determinants of FDI for developing countries with particular focus on African countries and considered natural resource and institutional environment as main determinants. These selection criterions are set intentionally to review only the existing literature closely related to this research. This filtering of existing literature lead to review a limited number of studies, as stated below, from the vast literature on FDI.

Asiedu (2002), using a sample of 71 developing countries from different developing regions and covering a sample period from 1988-1997, finds a country in the Sub-Saharan-Africa(SSA) receives on average less FDI relative to a country in other regions. Asiedu (2002) argues that Africa is different because the negative and significant effect of Africa dummy remains persistent even after controlling for trade openness, return to investment, and development of infrastructure although natural resource endowment is not considered in (Note 3). Asiedu's (2002) paper however excludes considering resource endowment as a determinant and considers political instability only as a measure of institutions and includes as an additional control. Rogoff and Reinhart (2003) brought a different perspective of the determinants of FDI to Africa however they also say that "Africa lags behind other regions in attracting foreign direct investment (FDI)" (Rogoff \& Reinhart, 2003, p. 1). They studied historical episodes of hyperinflation and currency crashes and argue that lack of transparency of monetary and exchange rate policies are responsible for the lack of FDI to Africa. In a later work, Asiedu (2006) includes resource endowment (measured by share of fuel and minerals in exports), the institutions (measured by control of corruption and rule of law) and lack political risks (no. of coups, assassinations, and riots) and finds that they promote FDI to SSA. However, in contrast to Asiedu (2002), Asiedu (2006) does not draw comparison across developing regions and considers only 22 African countries covering a sample period form 1984-2000.

Onyeiwu and Shrestha (2004) examine 29 African countries from 1975-1999 and find growth potential, macro stability, trade openness, and natural resource endowments (measured by share of fuel in exports) are significant determinants for FDI to Africa and political rights and good infrastructure are insignificant. In contrary, Dupasquier and Osakwe (2006) find that weak infrastructure, poor governance reduces FDI in Africa. However, they do not consider relative resource endowments. Naude and Krugell (2007) analyse three sets of determinants for 19 Africa countries from 1970-1990: policy (e.g., infrastructure, trade), institutions (e.g., political instability, regulatory burden, expropriation) and geography (e.g., climate, landlocked, latitude) and find strong evidence that lack of institutional quality (e.g. political instability, lack of rule of law, regulatory burden) reduce FDI flows to Africa; no evidence that policy constraints (e.g., infrastructure constraints) except high government 
consumption effect FDI; and do not find evidence that market size drives FDI to Africa or geography characteristics have a direct effect on FDI to Africa.

Ezeoha and Cattaneo (2012) examine the impacts of financial development, institutional quality (measured by corruption), and natural resource endowment (following binary dummy classification of IMF: 1 for resource-rich and 0 for non-resource-rich) in 30 SSA countries from 1995-2008 and find natural resource endowments, control of corruption, and financial development (measured as share of broad money to GDP) are a key factors in attracting FDI inflows however, they argue that the importance of resource as a determinant of FDI in SSA is declining since 2000. Anyanwu (2012) examines FDI data of 53 African countries from 1996-2008 and finds that resource endowments (measured by oil exports as dummy), along with market size, trade openness, and financial development, result in higher FDI inflows. Out of three institutional variables (Control of corruption, rule of law, and regulatory quality) examined, Anyanwu finds rule of law only promotes FDI.

The resource seeking motive of FDI has also been investigated in the context of bilateral FDI data from China to African countries intensively in bilateral FDI data from China to African countries (e.g., Kolstad \& Wiig, 2012, Cheung et al. (2012), Buckley et al. (2007). Arezki and Gylfason (2013) examine resource boom in SSA countries and their relationship with political regime and political risks. They find higher resource rent tends to increase corruption to a greater extent in less democratic countries, which otherwise suggests that stronger political institutions (i.e., a higher degree of democracy with checks and balance) tends to reduce corruption resulting from higher resource rent. However, they also find a higher resource rent leads to higher government spending in a less democratic government which helps to managing conflicts more effectively than a more democratic government. Cust and Harding (2014) look for the drivers of mining (oil and gas) exploration events in developing countries and provide evidence that institutional development (measured by e.g., political rights and democracy) increases substantially the numbers of mining exploration activities (no. of wells drilling) and they suggest this finding as an explanation of why some regions (e.g. SSA) still remain underexplored.

Kinda (2015) conducts a firm level study on 30 SSA countries and examines three main constraints: infrastructure, financing, and taxation. Kinda finds no evidence that tax incentives (e.g., lower tax rates for foreign firms) significantly affect FDI in Africa while other investment incentives, such as developed infrastructure (measured by telecommunication, transports, and electricity and consider PCA to reduce collinearity) significantly increase FDI to a larger extent, financing facilities (measured by access to local credit market) affect FDI depending on ownership structure (e.g., less influential for largely foreign-owned firms), higher stock of human capital (measured by skilled labour shortage) positively affect horizontal-FDI, better institutional quality (measured by crime and disorder) increases vertical-FDI.

IMF's World Economic Outlook (2015) reports that mineral resource explorations and improvements of institutional quality are positively associated with FDI in developing countries, particularly in Latin America and Caribbean and in the SSA. It is noteworthy that much improvement in institutional quality took place during the mid-1990s and since 2000 (perhaps institutions measurement has been revised and corrected) institutional development in the developing countries tends to move downward (as shown in Figure 3b). However, it is not clear whether improvement in institutional quality contributed to the regional shift in FDI when the trends of FDI and institutional development are compared side by side.

\section{Methodology and Data}

\subsection{Empirical Model}

This research considers 27 SSA countries, a sample of countries similar to Asiedu (2006) (Note 4). The estimated equation includes two competing forces: resource endowments and institutional quality as main determinants of FDI and four controls, commonly used in empirical literature of FDI to Africa, trade openness, level of infrastructure development, market size, and macroeconomic stability (Note 5).

The coefficients of interest are $\beta_{1}$ and $\beta_{2}$. If $\beta_{1}$ is statistically significant, then this suggests an independent effect of a resource-rich country on FDI and this effect does not disappear in the presence of either improvement or deterioration of institutional quality and in the presence of commonly used control variables. Similarly, if $\beta_{2}$ is statistically significant, then this suggests an independent effect of improvement or deterioration of institutional quality and this effect does not disappear in the presence of resource endowment or in the presence of the control variables. The estimated equation in logarithmic form is:

$$
\begin{aligned}
\log (\text { FDI per capita })_{i t}= & \mu_{i}+\beta_{1} \log (\text { Resources })_{i t}+\beta_{2} \text { Institutions }_{i}+\beta_{3} \log (\text { Infrastructure })_{i t}+ \\
& \beta_{4} \log (\text { GDP })_{i t}+\beta_{4} \log (\text { Trade })_{i t}+\log (\text { Inflation })_{i t}+\varepsilon_{i t}
\end{aligned}
$$

The dependent variable in equation (1) is log of FDI per capita inflows, which is relatively symmetric and 
approximately normally distributed compared to other normalization (i.e., FDI to GDP) and is commonly used in this literature (e.g., Asiedu, 2002, 2006). Resource endowments is measured using the sum of fuel and ores and metal exports as a share of total merchandise exports, as also used in Asiedu (2006). It is noteworthy that a wide range of institutional indexes are used to measure institutional environment of the capital recipient countries. Some studies used one or two specific institutional indexes leaving the other indexes, which is however not always well-grounded. A reason for ambiguous empirical impacts of institutional quality on FDI is due to the choices of different institutional indexes in different studies.

In contrast, this research uses an aggregated index of institutional quality (i.e., sum of 12 sub-indexes of ICRG political risks) instead of randomly using one or two specific institutional indexes. However, correlations among different indexes measuring institutional quality may lead to multicollinearity and this may limit the extent to which the relevance of each institutional dimension can be identified (Benassy-Quere, Coupet, \& Mayer, 2007). In order to address this issue, principal component analysis (PCA) is used that reduces the dimensionality of political risk indexes and examines which specific institutional index/indexes have the most influence in determining FDI to SSA. The PCA is a data-driven approach, which estimates the simultaneous effects of component factors that satisfy the criterion of having an associated eigenvalue strictly greater than 1 and examine the weights of different political risk indexes in any principal components that show up as statistically significant in the estimated Equation (1).

The choice of additional explanatory variables is standard in the existing literature. Openness to international trade is a relevant factor in the decision to invest, as trade influences both access to essential inputs as well as revenues from production in a tradable sector (e.g., Wheeler \& Mody, 1992; Asiedu. 2002). A country with better infrastructure tends to attract higher foreign direct investment. A well-developed infrastructure attracts foreign investors because it reduces transaction costs associated with investments and increases returns to investments. If a country does not have well-developed infrastructure facilities such as, telecommunication services, power supply, then the country is less attractive to the investors as the investment looks less productive. Commonly used measures of infrastructure in the existing literature are the percentage of paved roads in total roads, telephone lines per capita.

As used in previous studies (e.g., Asiedu, 2002; in Alfaro et al., 2008; Kinda, 2010) in this literature, the number of fixed phone lines per 100 people is used as a proxy for infrastructure development in our study. The inflation rate, measured as the annual percentage change in CPI, is used as a proxy for macroeconomic stability that is hypothesized to reduce uncertainty and increase confidence levels in the economy, which attracts higher FDI inflows.

\subsection{Data}

Table 2. Data, description and sources

\begin{tabular}{lll}
\hline Variable & Description & Sources \\
\hline FDI per capita & Foreign direct investment itself refers to net inflows of financial capital used by & WDI, World Bank (2014) \\
& a foreign owner to acquire a lasting controlling stake (usually defined as 10 & \\
& percent or more of the voting equity shares. FDI inflows data in current USD are & \\
& divided by population. & \\
Resource endowment & Share of fuel (SITC 3), ores and metal (SITC 27, 28, 68) exports as percentages & WDI, World Bank (2015) \\
& of merchandise exports. & \\
Institutional quality & Sum of 12 indexes of political risks of ICRG: government stability, & Political Risk Services \\
& socioeconomic conditions, internal conflicts, external conflicts, corruption, & (ICRG), 2015 \\
& military in politics, religious tensions, law and order, ethnic tensions, democratic & \\
Infrastructure & accountability, and bureaucratic quality. & WDI, World Bank (2015) \\
GDP & Fixed telephone subscriptions (per 100 people) & WDI, World bank (2015) \\
Trade & GDP at current market prices & WDI, World Bank (2015) \\
Inflation & Sum of exports and imports as a percentage of GDP & WDI, World Bank (2015) \\
\hline
\end{tabular}

\section{Results and Discussion}

Table 3 reports OLS (using cross-sectional averages), pooled OLS and panel fixed effects (using 3 years window averages) estimates. The base models (Model 1, 3 and 5) consider only resource endowment and institutional quality as the determinants of FDI. Models 2, 4, 6, and 7 include four main controls (infrastructure, trade openness, 
market size, and macroeconomic stability), which are commonly used as potential determinants in FDI literature.

Between the two competing determinants (resource endowment and institutional quality) of FDI, the finding suggests that resource endowment has both statistically and quantitatively greater impact on FDI to SSA. In particular, resource endowment has a robust and significant positive effect on FDI across different estimation approaches (in full model estimates of Models 2, 4 and 7 in Table 3).

A potential concern with the cross-section results is that the data could miss important dynamic effects in FDI flows by taking averages over a longer period. Time variation effects of the two competing determinants are used in pooled OLS estimator that suggests resource endowment and institutional quality both have statistically significant effects on FDI in the presence of other potential determinants (Model 4 in Table 3). This result, in contrast to cross sectional averages (Model 2 in Table 3), may suggest that cross-section averages failed to capture time-series variation effect of institutional environment on FDI and is realized in pooled OLS estimates. However, cross-section OLS and pooled OLS both failed to capture country specific time-invariant effects that are potentially important determinants for FDI in SSA. The time-invariants effects are resulting from country-specific characterises (e.g., social norms, culture, geography). It is obvious that there are substantial differences in the characteristics across the countries despite our country sample is taken from the same region (i.e., SSA countries). The fixed effects (FE) estimator is more likely to reduce the bias in the estimates resulting from unobserved country-specific heterogeneity and to provide more convincing estimates of the true effect of the main variables of interest (e.g., the institutional quality and resource endowment).

Panel fixed effects estimates (Models 5, 6, and 7 in Table 3) suggests that, after controlling for country-specific effects, institutional environment is no longer a significant determinant for FDI, however, resource endowment is positive and significantly increases FDI to SSA. Moreover, the effects of resource endowment on FDI remain positive and significant even after controlling for common time shocks (Model 7 in Table 3). In panel fixes effects model, the other important determinant of FDI to SSA countries is infrastructure (telephone line per 100 people) and it remains as a statistically significant determinant of FDI even after controlling for country and time fixed effects (Model 7 in Table 3).

Based on the estimates derived from different estimation approaches, a- one-standard-deviation increase in resource endowment in the SSA countries increases FDI ranging from $34 \%$ to $83 \%$ (Note 6). On the other hand, institutional environment, measured as an aggregate index of institutional quality, is not a robust determinant for FDI as the significant effect of institutional environment is disappeared once other potential explanations of FDI are included in the models (e.g., Models 2, 6 and 7 in Table 3).

The insignificant effects of institutional quality on FDI may refer to the challenge in existing FDI literature of precise measure of institutional environment. Alfaro et al. (2008) add 12 ICRG indexes to measure institutional quality. Others use these indexes by grouping them into small number of aggregated indexes that capture similar dimensions (see, for example, Daude \& Stein, 2007). However, this grouping of ICRG indexes are not consistent across different studies which may suggest a potential explanation why different studies find different specific institutional aspect as important determinant of FDI. In contrast to this approach, we extract information from institutional quality using principal components analysis (PCA) and analyse if a particular aspect(s) of the institutional quality significantly determines FDI to SSA countries.

We find first 3 principal components having an associated eigenvalue strictly greater than one, as reported in Table 4. In the first principal component, Internal Conflict Absent and Expropriation Risk Absent have the largest weights. In particular, the weights on individual political risk variables in the first principal component of the ICRG indexes, as reported in Table 4, assign the largest factor loadings to Internal Conflict Absent (0.89) and the $2^{\text {nd }}$ largest to Expropriation Risk Absent (0.81). The order of this factor loadings in first principal component remains the same across OLS, pooled OLS, and panel averaging.

Table 5 reports PCA results and suggests that the first principal component has statistically significant effects on FDI in OLS and pooled OLS estimators meaning that FDI flows are higher in the SSA countries where Internal Conflict and Expropriation Risk are relatively lower. However, the significant effect does not survive once we controlled for country specific fixed effects. The FE estimates suggest that resource endowment is the only significant determinant of FDI to SSA and none of the principal components has significant effect. The PCA-based regression results also support our findings and suggest that the resource endowment is a robust determinant of FDI to SSA countries.

Infrastructure (measured by telephone line per 100 people) emerges as a statistically significant and strong determinant of FDI in the SSA countries. Telephone line per capita is a statistically significant determinant of FDI in both pooled OLS and fixed effects models but it didn't show up as a significant determinant in 
cross-section estimates. Cross-section model is relatively a weaker estimation method compared to pooled and fixed effects methods. The estimated models by pooled OLS are able to capture the effects of time series variation and the estimated models by fixed effects are able to capture time series variation as well as to control for time-invariant factors in the models. We argue that pooled and fixed effects estimates are hence relatively stronger and more reliable estimates than cross-section estimates.

It is argued in recent commentary reports (e.g., World Bank, June, 2015) that FDI to SSA countries is shifting from resource sectors to manufacturing sectors. And manufacturing FDI to Africa is market seeking instead of efficiency seeking and the main determinants of manufacturing FDI are market size and market potential (World Bank 2015). This research examines whether an additional control in addition to market size can make resource endowments to the foreign investors in the SSA countries. In particular, the share of manufacturing value added to GDP is included in regression model; however, the result suggests that inclusion of manufacturing value added to GDP cannot reduce the significant effects of resource endowment as a determinant of FDI in SSA countries (Note 7). This finding suggests us that even if market size is a significant determinant of FDI in SSA countries and a larger share of FDI targeting to manufacturing sectors; however, the independent effect of resource endowment still remains a robust determinant of FDI and explains the recent trend of FDI flows to SSA countries.

Table 3. Cross section OLS, Pooled OLS and fixed effects: dependent variable: Log of FDI per capita

\begin{tabular}{|c|c|c|c|c|c|c|c|}
\hline \multirow[t]{2}{*}{ VARIABLES } & \multicolumn{2}{|c|}{ OLS } & \multicolumn{2}{|c|}{ Pooled OLS } & \multicolumn{3}{|c|}{ Fixed Effects } \\
\hline & $(1)$ & (2) & (3) & (4) & (5) & (6) & (7) \\
\hline \multirow[t]{2}{*}{ Log Resource Endowment } & $0.497 * * *$ & $0.420 * * *$ & $0.447 * * *$ & $0.279 * * *$ & $0.412 * * *$ & $0.177 * *$ & $0.159 *$ \\
\hline & $(0.130)$ & $(0.127)$ & $(0.046)$ & $(0.047)$ & $(0.105)$ & $(0.077)$ & $(0.080)$ \\
\hline \multirow[t]{2}{*}{ Institutional Environment } & $0.043 * * *$ & 0.019 & $0.046^{* * *}$ & $0.019 * * *$ & -0.029 & 0.011 & -0.002 \\
\hline & $(0.012)$ & $(0.016)$ & $(0.006)$ & $(0.006)$ & $(0.033)$ & $(0.025)$ & $(0.026)$ \\
\hline \multirow[t]{2}{*}{ Log (Phone per 100 people) } & & 0.223 & & $0.239 * * *$ & & $0.419 * *$ & $0.407 * *$ \\
\hline & & $(0.198)$ & & $(0.085)$ & & $(0.203)$ & $(0.198)$ \\
\hline \multirow[t]{2}{*}{ Log GDP } & & -0.022 & & $0.258 * * *$ & & $1.018^{* * *}$ & $1.529 * * *$ \\
\hline & & $(0.120)$ & & $(0.062)$ & & $(0.110)$ & $(0.384)$ \\
\hline \multirow[t]{2}{*}{ Log Trade } & & $1.356^{*}$ & & $1.564 * * *$ & & $0.830^{*}$ & $1.241^{* *}$ \\
\hline & & $(0.684)$ & & $(0.277)$ & & $(0.488)$ & $(0.553)$ \\
\hline \multirow[t]{2}{*}{ Log Inflation } & & 0.004 & & 0.023 & & -0.188 & $-0.261^{*}$ \\
\hline & & $(0.208)$ & & $(0.062)$ & & $(0.126)$ & $(0.136)$ \\
\hline Observations & 27 & 26 & 297 & 256 & 123 & 113 & 113 \\
\hline R-squared & 0.528 & 0.690 & 0.291 & 0.456 & 0.725 & 0.886 & 0.893 \\
\hline Country FE & & & & & YES & YES & YES \\
\hline Year FE & & & & & NO & NO & YES \\
\hline
\end{tabular}

Note. Robust standard errors in parentheses. *** Significant at 1\%,** Significant at 5\%, * significant at 10\%. Models (1) and (2) present OLS estimates of cross section averages from 2000-2014; Models 3 and 4 present pooled OLS estimates from 2000-2014; Models (5), (6), (7) present Fixed Effects estimates of 3-year averages windows of 2000-2014.

Table 4. Factors Loadings: cross-section averaged (2000-2014), 3-year window panel averaged

\begin{tabular}{|c|c|c|c|c|c|c|c|c|c|}
\hline \multirow[b]{2}{*}{ ICRG Indexes } & \multicolumn{3}{|c|}{ Cross section } & \multicolumn{3}{|c|}{ Pooled } & \multicolumn{3}{|c|}{ Panel } \\
\hline & Factor 1 & Factor 2 & Factor 3 & Factor 1 & Factor 2 & Factor 3 & Factor 1 & Factor 2 & Factor 3 \\
\hline Expropriation Risk Absent & 0.81 & 0.34 & 0.02 & 0.77 & 0.33 & -0.08 & 0.76 & 0.35 & -0.05 \\
\hline Government Stability & 0.5 & 0.27 & -0.66 & 0.43 & 0.38 & 0.59 & 0.44 & 0.36 & 0.63 \\
\hline Socioecon Stress Absent & 0.58 & 0.58 & 0.25 & 0.56 & 0.55 & -0.22 & 0.57 & 0.58 & -0.23 \\
\hline Internal Conflict Absent & 0.89 & 0.14 & -0.13 & 0.81 & 0.14 & 0.1 & 0.84 & 0.12 & 0.08 \\
\hline External Conflict Absent & 0.68 & 0.47 & 0.23 & 0.64 & 0.42 & -0.33 & 0.67 & 0.41 & -0.31 \\
\hline Corruption Absent & 0.69 & 0.01 & -0.2 & 0.59 & 0.09 & -0.3 & 0.64 & 0.06 & 0.23 \\
\hline Military Not in Politics & 0.72 & -0.36 & 0.36 & 0.72 & -0.35 & 0.29 & 0.73 & -0.35 & -0.29 \\
\hline Religious Tensions Absent & 0.66 & -0.15 & -0.11 & 0.64 & -0.13 & 0.17 & 0.65 & -0.14 & 0.15 \\
\hline Law and Order & 0.67 & -0.41 & -0.28 & 0.66 & -0.36 & 0.32 & 0.66 & -0.36 & 0.33 \\
\hline Ethnic Tensions Absent & 0.76 & -0.41 & -0.04 & 0.74 & -0.43 & 0.09 & 0.74 & -0.43 & 0.09 \\
\hline Democratic Accountability & 0.7 & -0.28 & 0.03 & 0.67 & -0.27 & -0.04 & 0.67 & -0.27 & -0.05 \\
\hline Bureaucratic Quality & 0.52 & -0.13 & 0.55 & 0.5 & -0.17 & -0.53 & 0.5 & -0.17 & -0.53 \\
\hline Eigenvalues & 5.7 & 1.35 & 1.14 & 5.12 & 1.31 & 1.11 & 5.29 & 1.33 & 1.11 \\
\hline
\end{tabular}


Table 5. Principal factors:OLS, Pooled OLS, FE: Dependent variable: Log of FDI per capita

\begin{tabular}{lccc}
\hline VARIABLES & OLS & Pooled OLS & Fixed Effects \\
& $(1)$ & $(2)$ & $0.175^{* *}$ \\
\hline Log Resource Endowment & $0.389^{* * *}$ & $0.261^{* * *}$ & $(0.078)$ \\
& $(0.125)$ & $(0.048)$ & 0.017 \\
Institutions Environment & & & $(0.352)$ \\
Factor 1 & $0.452^{* *}$ & $0.263^{* * *}$ & -0.118 \\
& $(0.213)$ & $(0.091)$ & $(0.305)$ \\
Factor 2 & 0.346 & -0.117 & 0.083 \\
& $(0.218)$ & $(0.094)$ & $(0.261)$ \\
Factor 3 & -0.048 & $0.223^{* *}$ & $0.376^{*}$ \\
& $(0.167)$ & $(0.092)$ & $(0.213)$ \\
Log (Phone per 100 people) & 0.134 & $0.272^{* * *}$ & $0.989^{* * *}$ \\
& $(0.188)$ & $(0.089)$ & $(0.117)$ \\
Log GDP & 0.056 & $0.288^{* * *}$ & 0.796 \\
& $(0.111)$ & $(0.065)$ & $(0.509)$ \\
Log Trade & 1.133 & $1.576^{* * *}$ & -0.183 \\
& $(0.675)$ & $(0.276)$ & $(0.129)$ \\
Log Inflation & 0.115 & 0.023 & 113 \\
Observations & $(0.236)$ & $(0.062)$ & 0.885 \\
R-squared & 26 & 256 & YES \\
Country FE & 0.726 & 0.473 & \\
\hline
\end{tabular}

Note. Robust standard errors in parentheses. *** Significant at 1\%, ** Significant at 5\%, * significant at $10 \%$.

\section{Conclusion}

This empirical analysis presents a relatively clear answer to the research question of whether resource endowment or institutional quality determined the increased flows of FDI to the SSA countries. Empirical findings of this research suggest that resource endowment does increase FDI to SSA countries and is a robust determinant. In contrast to the existing literature this analysis suggests that institutional quality determines FDI; however, is not a robust determinant of FDI. This finding also confirms that the effect of resource endowment on FDI is robust in the presence of other potential important determinants of FDI such as trade openness, macroeconomic stability, levels of infrastructure development, and the market size. In particular, infrastructure (measured by telephone line per 100 people) plays a significant role and attracts substantial amount of FDI to SSA countries where infrastructure facilities are relatively better. This finding suggests a relatively clearer explanation of why SSA countries are no longer lacking in the race of acquiring global share of FDI. In contrast to the findings of existing studies in this literature (e.g., Asiedu, 2006), our research clearly suggests resource endowment not institutional quality is a driving force in attracting FDI in the SSA countries. A concern of such resource seeking FDI is that if SSA countries lack in resource endowment, little or no FDI will flow to the resource poor countries. The policymakers in the SSA countries need to tailor FDI policies (e.g., by reducing profit repatriation and developing linkage industries in domestic markets for FDI) to realize more benefits from FDI. An appropriate FDI policies are important for SSA countries to make FDI work for long-term growth and economic development of the SSA countries.

\section{References}

Akhtaruzzaman, M., Berg, N., \& Lien, D. (2017). Confucius Institutes and FDI flows from China to Africa. China Economic Review, 44, 241-252. https://doi.org/10.1016/j.chieco.2017.02.004

Akhtaruzzaman, M., Berg, N., \& Hajzler, C. (2017). Expropriation risk and FDI in developing countries: Does return of capital dominate return on capital? European Journal of Political Economy, 49, 84-107. https://doi.org/10.1016/j.ejpoleco.2017.01.001

Akhtaruzzaman, M., Hajzler, C., \& Owen, P. D. (2018). Does institutional quality resolve the Lucas Paradox? Applied Economics, 50(5), 455-474. https://doi.org/10.1080/00036846.2017.1321840

Alfaro, L., Kalemli-Ozcan, S., \& Volosovych, V. (2008). Why Doesn't Capital Flow from Rich to Poor Countries? An Empirical Investigation. Review of Economics and Statistics, 90(2), 347-368. https://doi.org/10.1162/rest.90.2.347 
Anyanwu, J. C. (2012). Why Does Foreign Direct Investment Go Where It Goes? New Evidence from African Countries. Annals of Economics and Finance, 13(2), 425-462.

Arezki, R., Gylfason, T., \& Sy, A. (2012). Beyond the Curse: Policies to Harness the Power of Natural Resources. Africa Growth Agenda, pp. 12-14.

Asiedu, E. (2006). Foreign Direct Investment in Africa: The role of Natural Resources, Market Size, Government Policy, Institutions and Political Instability. World Economy, 29(1), 63-77. https://doi.org/10.1111/j.1467-9701.2006.00758.x

Asiedu, E. (2002). On the Determinants of Foreign Direct Investment to Developing Countries: Is Africa different? World Development, 30(1), 107-119. https://doi.org/10.1016/S0305-750X(01)00100-0

Bénassy-Quéré, A., Coupet, M., \& Mayer, T. (2007). Institutional Determinants of Foreign Direct Investment. World Economy, 30(5), 764-782. https://doi.org/10.1111/j.1467-9701.2007.01022.x

Buckley, P. J., Clegg, L. J., Cross, A. R., Liu, X., Voss, H., \& Zheng, P. (2007). The Determinants of Chinese Outward Foreign Direct Investment. Journal of International Business Studies, 38(4), 499-518. http://dx.doi.org/10.1057/jibs.2008.102

Cheung, Y. W., de Haan, J., Qian, X., \& Yu, S. (2012). China's Outward Direct Investment in Africa. Review of International Economics, 20(2), 201-220. https://doi.org/10.1111/j.1467-9396.2012.01017.x

Daude, C., \& Stein, E. (2007). The Quality of Institutions and Foreign Direct investment. Economics \& Politics, 19(3), 317-344. https://doi.org/10.1111/j.1468-0343.2007.00318.x

Dupasquier, C., \& Osakwe, P. N. (2006). Foreign Direct Investment in Africa: Performance, Challenges, and Responsibilities. Journal of Asian Economics, 17(2), 241-260. https://doi.org/10.1016/j.asieco.2005.07.002

Ezeoha, A. E., \& Cattaneo, N. (2012). FDI Flows to Sub-Saharan Africa: The impact of finance, institutions, and natural resource endowment. Comparative Economic Studies, 54(3), 597-632. https://doi.org/10.1057/ces.2012.18

Kinda, M. T. (2014). The Quest for Non-Resource-Based FDI: Do Taxes Matter? International Monetary Fund. No. 14-15.

Kinda, T. (2010). Increasing private capital flows to developing countries: The role of physical and financial infrastructure in 58 countries, 1970-2003. Applied Econometrics and International Development, 10(2), 57-72.

Kolstad, I., \& Wiig, A. (2012). What Determines Chinese Outward FDI? Journal of World Business, 47(1), 26-34. https://doi.org/10.1016/j.jwb.2010.10.017

Naudé, W. A., \& Krugell, W. F. (2007). Investigating Geography and Institutions as Determinants of Foreign Direct Investment in Africa Using Panel Data. Applied Economics, 39(10), 1223-1233. https://doi.org/10.1080/00036840600567686

Nunnenkamp, P., \& Spatz, J. (2002). Determinants of FDI in Developing Countries: Has Globalization Changed the Rules of the Game? Transnational Corporations, 11(2), 1-34. Retrieved from: https://www.econstor.eu/handle/10419/2797

Onyeiwu, S., \& Shrestha, H. (2004). Determinants of Foreign Direct Investment in Africa. Societies Journal of Developing, 20(1-2), 89-106. https://doi.org/10.1177/0169796X04048305

Reinhart, M. C., \& Rogoff, M. K. (2003). FDI to Africa: The Role of Price Stability and Currency Instability. International Monetary Fund: No. 3-10.

UNCTAD. (2015). World Investment Report 2015: Transnational Corporations. New York: United Nations Publications.

Wheeler, D., \& Mody, A. (1992). International Investment Location Decisions: The Case of US Firms. Journal of International Economics, 33(1), 57-76. https://doi.org/10.1016/0022-1996(92)90050-T

IMF. (2011). World Economic Outlook Report: April 11, 2011.

IMF. (2015). World Economic Financial Survey. World Economic Outlook, Report: October, 2015.

World Bank. (2014). World Development Indicators. Washington, DC: World Bank.

World Bank. (2015). Manufacturing FDI in Sub-Saharan Africa: Trends Determinants and Impact. Washington, DC: 
http://www.worldbank.org/content/dam/Worldbank/Event/Africa/Investing\%20in\%20Africa\%20Forum/201 5/investing-in-africa-forum-manufacturing-fdi-in-sub-saharan-africa-trends-determinants-and-impact.pdf

\section{Notes}

Note 1. FMs in Africa are Angola, Ghana, Kenya, Mauritius, Mozambique, Nigeria, Senegal, Tanzania, South Africa, Uganda, Zambia, and Zimbabwe (WEO, April 2011).

Note 2. Figures are drawn based on the data spanning the sample period used for the empirical analysis of this paper.

Note 3. SSA includes all African countries that lie south of the Sahara Desert excluding seven African countries lie in northernmost region of Africa. Africa is used is this research would imply the SSA.

Note 4. Selection of countries is subject to the availability of data on the main variables (FDI, resource endowments, institutional quality). Our sample extends Asiedu's (2006) SSA countries to 27 and our sample period covers more recent period.

Note 5. A main reason to include these determinants is to compare the findings of this research with most cited studies examined the determinants of FDI to Africa.

Note 6. One standard deviation calculations are based on coefficient estimates and sample standard deviation, as follows. In OLS: 0.42 (full-model coefficient estimates, Model 2) x 1.98 (cross-section averaged sample standard deviation) $=0.83$. In FE: 0.16 (full-model coefficient estimates Model 7) x 2.12 (3-year panel averaged sample standard deviation) $=0.34$.

Note 7. Results are not reported in the regression tables and are available on request.

\section{Copyrights}

Copyright for this article is retained by the author(s), with first publication rights granted to the journal.

This is an open-access article distributed under the terms and conditions of the Creative Commons Attribution license (http://creativecommons.org/licenses/by/4.0/). 